Original Research Paper

\title{
Mengenal Dampak Negatif Penggunaan Zat Adiktif pada Makanan terhadap Kesehatan Manusia
}

\author{
M Yamin*) \\ Program Studi Pendidikan Biologi, Fakultas Keguruan dan Ilmu Pendidikan, Universitas Mataram, Indonesia
}

DOI: https://doi.org/10.29303/jpmpi.v3i2.517

Sitasi : Yamin. (2020). Mengenal Dampak Negatif Penggunaan Zat Adiktif pada Makanan terhadap Kesehatan Manusia. Jurnal Pengabdian Magister Pendidikan IPA, 3(2)

\author{
Article history \\ Received: 28 Oktober 2020 \\ Revised: 10 Nopember 2020 \\ Accepted: 27 Nopemeber 2020 \\ *Corresponding Author: \\ M. Yamin, \\ Program Studi Pendidikan \\ Biologi, Fakultas Keguruan dan \\ Ilmu Pendidikan, Universitas \\ Mataram, Indonesia; \\ Email: \\ yamin_fkip@hotmail.com
}

\begin{abstract}
Abstrak: Penggunaan zat aditif berupa bahan pengawet, penyedap, pemanis mapun suplemen pada makanan dewasa ini tidak dapat dihindari untuk menjamin persediaan dan peningkatan mutu makanan, namun sangat sedikit orang yang tahu, sadar dan peduli terhadap dampak negatifnya. Tulisan ini menyajikan informasi menegenai dampak negatif penggunaan zat adiktif pada makanan terhadap kesehatan manusia. Tujuannya untuk memberikan kesadaran dan meningkatkan kesehatan masyarakat agar tercipta masyaraakat yang sehat dan kuat untuk melaksanakan pembangunan bangsa.
\end{abstract}

Kata kunci: Makanan, Zat, Aditif

\section{Pendahuluan}

$\mathrm{P}$ raktikum Penggunaan zat aditif berupa bahan pengawet, penyedap, pemanis mapun suplemen pada makanan dewasa ini tidak dapat dihindari untuk menjamin persediaan dan peningkatan mutu makanan. Selain manfaatnya seperti tersebut, zat aditif juga dapat berdampak negatif terhadap kesehatan manusia, namun hanya sedikit orang yang mengetahuinya.

Bahan tambahan dalam makanan (food additives) merupakan substansia yang secara sengaja digunakan sebagai tambahan pada makanan, setelah menjadi komponen dari makanan akan mempengaruhi sifat dan kualitas makanan baik secara langsung maupun tidak langsung (OSER, 1975 Cit. Harminasi, 1987). Sejalan dengan berkembang dan berubahnya kondisi lingkungan hidup manusia serta ilmu pengetahauan. Pada tahun 1980, Holdgate telah mengkategorikan "food additives" sebagai pencemar lingkungan, karena dengan adanya bahan tambahan dalam makanan baik yang dimasukan secara sengaja untuk tujuan tertentu, tetapi karena sesuatu sebab atau proses yang tidak disengaja, bahkan mungkin tanpa sepengetahuan manusia baik sebagai produsen maupun sebagai konsumen. Pencemaran Lingkungan menurut Miller (1975) pada dasarnya adalah setiap material atau rangkaian keadaan yang menimbulkan suatu perubahan yang tidak menguntungkan atas mahluk hidup, baik pada tingkat individu, populasi, komunitas ataupun ekosistem, dibawah keadaan lingkungan normal.

Manusia pada saat ini menurut Jackson (1974) berada dalam suatu segitiga krisis, dengan populasi manusia, sumberdaya dan pencemaran lingkungan pada masing-masing titik sudutnya. Usaha manusia untuk meningkatkan mutu dan kualitas dari makanan maka manusia menggembangkan food additives, antara lain sebagai bahan pengawet, pewarna, penyedap dan pemanis. Bahan-bahan tambahan tersebut dapat berupa bahan organik, ataupun anorganik yang memungkinkan bahan dasar makanan tetap dalam bentuk aslinya akan tetapi memungkinkan pula bahan-bahan dasar makan mengalami perubahanperubahan akibat terjadinya reaksi-reaksi selama proses penyimpannya. 
Penggunaan zat aditif pada makanan yang tidak bijaksana dapat menimbulkan berbagai masalah kesehatan misalnya keracunan, kerusakan syaraf, ginjal, hati, cacat kelahiran, gangguan gastroenteritis, kejang-kejang, anomalia kaki, kelainan pertumbuhan, kemandulan bahkan kematian. Sehubungan dengan hal tersebut, untuk menhindari dan mengurangi dampak negatif seperti tersebut perlu mendapat perhatian dari insan akademis dari perguruan tinggi untuk menyampaikan informasi mengenai ancaman keracunan oleh adanya bahan-bahan tambahan dalam makanan dalam rangka meningkatkan kesadaran dan kesehatan masyarakat agar tetap sehat dan kuat untuk melaksanakan pembangunan bangsa.

\section{Metode}

Metode yang digunakan dalam kegiatan ini adalah metode cerama/ penyuluhan, diskusi dan demonstrasi kepada khalayak sasaran. Kegiatan ini melibatkan dikuti oleh 30 orang siwa, pegawai dan guru di SMP Negri 4 Gunungsari Kabupaten Lombok Barat. Untuk meningkatkan kesadaran dan pengetahuan khalayak sasaran yaitu siswa SMP Negeri 4 Gunungsari Kecamatan Gunungsari Kabupaten Lombok Barat, tim pengusul kegiatan melakukan dua macam kegiatan yaitu Penyulahn dan demonstrasi. Pada tahap pelaksanaan ada dua kegiatan yang dilakukan yaitu 1) penyuluhan untuk penyampaian materi pengaruh zat aditif padamakanan terhadap kesehatan; 2) Demontrasi contoh jeni-jenis makanan yang mengandung zat aditif. Pelaksanaan : Kegiatan Pengabdian ini telah dilaksanakan pada 08 September tahun 2020 di Siswa SMP Negri 4 Gunungsari Kabupaten Lombok Barat.

\section{Hasil dan Pembahasan}

Bahan tambahan dalam makanan (food additives) merupakan substansia yang secara sengaja digunakan sebagai tambahan pada makanan, setelah menjadi komponen dari makanan akan mempengaruhi sifat dan kualitas makanan baik secara langsung maupun tidak langsung (oser, 1975 cit. Harminasi, 1987). Tulisan ini dimaksudkan untuk menyebarkan informasi dan memberikan pengetahuan kepada masyarakat agar dapat melakukan observasi dan evaluasi terhadap produk yang dijual di pasaran (toko-toko, super
Market, dll). Dengan bekal pengetahuan dan informasi tersebut, mereka menjadi lebih berhatihati dan selektif dalam mengkonsumsi dan/atau memakai produk makanan dan kosmetik termasuk sabun yang diimpor. Lebih-lebih dalam era serba keterbukaan seperti sekarang ini, termasuk pasar bebas sangat memungkinkan berbagai bentuk produk luar negeri tersedia dan diperjual-belikan secara bebas dimana-mana. Khusus untuk komsumen MUSLIM hendaknya lebih berhati-hati dengan produk luar (impor). Berikut diuraikan sejumlah dampak negatif zat aditif pada makanan terhadap kesehatan manusia.

1. Bahan Makanan dan Zat Aditif pada Makanan dan Dampaknya terhadap Kesehatan Manusia

Bahan makanan mengandung unsur-unsur pembangun tubuh yang sangat diperlukan bagi pertumbuhan dan perkembangan. Disamping itu, bahan makanan juga merupakan bahan yang sangat diperlukan untuk kesehatan tubuh. Namun dapat terjadi sebaliknya, bahan makanan menjadi sumber kerusakan atau kemerosotan kesehatan, sangat tergantung pada jenis bahan makanan dan kebersihan dan teknologi pengolahannya.

Sekarang ini, dimana-mana termasuk di lingkungan sekolah sangat mudah kita menemukan berbagai jenis makanan jadi, baik hasil olahan teknologi industri (kalengan, bungkusan), maupun yang buatan sendiri (es kelapa muda, cendol, bubur, lontong, pelecing dan sebagainya). Sangat memprihatinkan kita semua, bahwa bahan makanan yang dijajakan itu masih sangat banyak yang tidak memenuhi kreteria kesehatan, baik dilihat dari nilai gizi, kebersihan dan keamanannya bagi kesehatan. Adakah kita pernah peduli dan menyadarinya?

Bahan tambahan pada makanan diartikan sebagai bahan yang secara sengaja ditambahkan pada bahan makanan yang dapat mempengaruhi sifat atau kualitas makanan tersebut, baik secara langsung maupun tidak langsung (Oser, 1975 dalam Tandjung, 1987). Sejalan dengan perkembangan ilmu pengetahuan dan teknologi, bahan tambahan pada makanan dikategorikan sebagai bahan pencemar lingkungan (Holdgate, 1980). Pengkategorian sebagai bahan pencemar, karena kehadiran bahan tambahan tersebut dapat terjadi secara disengaja atau tidak disengaja. 
Kehadiran bahan tambahan pada makanan secara tidak disengaja, manusia sama sekali tidak mengetahui atau menyadarinya, baik dia sebagai produsen maupun konsumen pada semua jenis bahana makanan seperti makanan pokok, lauk pauk, sayuran dan buah-buahan.

Fungsi Makanan sebagai sumber energi, Makanan Sumber Energi, zat pembangun tubuh, pengatur, dan suplemen. Pada dasarnya, manusia selalu berusaha untuk memperoleh bahan pangan yang bermutu tinggi dengan penampakan yang sesuai dengan selera. Untuk tujuan ini, sejak lama manusia telah banyak mengembangkan penggunaan bahan-bahan tambahan makanan. Bahan tambahan makanan tersebut berfungsi sebagai pengawet, pewarna, pemanis, penyedap rasa, penambah aroma, penggumpal atau pengenyal dan sebagainya.

Bahan makanan termasuk kualitas gizinya mutlak diperlukan untuk pertumbuhan, perkembangan dan kesehatan. Jenis dan fungsi bahan makanan sangat bervariasi. Dengan perkembangan teknologi, bahan makanan yang dikonsumsi oleh konsumen tidak 100\% murni zat makanan, melainkan telah dibumbui dengan berbagai jenis bahan tambahan makanan. Bahan tambahan makanan secara umum dikelompokkan menjadi dua macam yaitu: (1) bahan tambahan makanan langsung dan (2) bahan tambahan makanan tidak langsung. Kedua kelompok bahan tambahan makanan tersebut mempunyai efek negatif terhadap kesehatan, pertumbuhan dan perkembangan konsumennya.

2. Bahan Makanan Tambahan Berupa Residu Bahan Kimia dan Suplemen Pengaruhnya terhadap Kesehatan Manusia

Kontaminan berbahaya bagi kesehatan dapat tersalurkan kepada konsumen karena mengkonsumsi produk-produk yang terkontaminasi. Kontaminan tersebut dapat berupa logam berat, residu bahan kimia (misalnya pestisida), residu hormon dan antibiotik. Kontaminan logam berat dapat semakin bertambah konsentrasinya karena pabrik, isdustri, pembangkit listrik bertenaga nuklir, perang dan uji coba senjata nuklir. Ada juga jenis tertentu umbi-umbian, daun, buah dan biji, yang kandungan logamnya, terutama seng
(Zn) yang tinggi menjadikan dia sangat beracun. Kentang dengan zat kandungannya solanin juga bersifat meracuni. Residu pestisida dapat menjadi ancaman serius kesehatan berkaitan dengan rendahnya pengetahuan para petani dalam menangani tanaman pertanian dengan menggunakan pestisida. Demikian juga dengan residu hormonal dan antibiotik pada hewan ternak budidaya. Dengan maksud memicu pertambahan berat badan dan pertumbuhan yang cepat digunakan hormon dan antibiotik, yang pada gilirannya apabila produk daging hewan tersebut dikonsumsi dapat menimbulkan pengaruh negatif terhadap konsumennya.

Kubis dan lobak, dengan zat penghambat penyerapan yodium (zat goitrogen) bisa menyebabkan penyakit gondok. Penyakit kanker (karsinogen), dapat terjadi karena mengkonsumsi makanan yang diberi zat aditif (zat tambahan) seperti: bahan pengawet, pewarna, penyedap rasa, pemanis buatan, dan pengemulsi. Bahan aditif makanan ini juga merupakan zat-zat beracun yang sangat berbahaya bagi tubuh. Penyakit kanker dapat menyerang organ lambung, kolon (usus besar), payu dara dan indung telur. Kanker lambung terjadinya karena zat nitrit dan nitrat dari makanan berubah menjadi nitrosamin yang bersifat karsinogenik. Kanker usus besar, bisa timbul karena bahan makanan yang dikonsumsi mengandung serat rendah dan lemak tinggi. Suatu saat lemak bisa berubah menjadi zat yang bersifat karsinogenik. Kanker payu dara dan indung telur, terjadi karena kadar lemak tinggi.

Kadar lemak tinggi berhubungan dengan pengubahan keseimbangan hormonal (terutama peningkatan hormon estrogen). Senyawa hidrokarbon yang timbul ketika pemrosesan makanan (misalnya dengan pengasapan dan penggorengan dengan suhu tinggi) sangat membahayakan kesehatan. Penyakit kardiovaskuler, merupakan kelanjutan penyakit tekanan darah tinggi, kebiasan merokok, dan kenaikan kolesterol serum. Penyakit ini sangat erat kaitannya dengan jenis makanan yang dikonsumsi (daging, lemak, seafood dan sebagainya) dan kebiasaan negatif lainya (merokok). Lemak hewani dapat menaikan kadar lemak serum, akibabnya kolesterol serum tinggi, pembuluh darah menyempit dan tekanan darah tinggi. Kelompok makanan yang berhubungan dengan penyakit ini adalah: bahan 
makanan dengan kandungan serat kasar rendah, gula, garam dan protein tinggi, mineral air minum rendah, dan perbandingan antara lemak jenuh dan lemak tak jenuh ganda yang amat tinggi.

Dalam teknologi perternakan, khusus dalam hewan budidaya digunakan zat memicu pertumbuhan berupa hormon dan senyawasenyawa arsenical. Hormon dan senyawa arsenical ini diberikan kepada hewan-hewan ternak beberapa saat maupun selama hidupnya (Tandjung, 1987). Pemberian bahan tambahan makanan pemicu pertambahan berat badan secara cepat (misalnya estrogen sintetik DES), jauh lebih berbahaya dibanding dengan pemberian hormon dan senyawa arsenical yang disebutkan diatas. Mengkunsumsi bahan makanan (daging, telur dan sebagainya) yang mengandung DES (diethylstilbestrol) dapat menyebabkan terjadinya tumor pada saluran kelamin gadis-gadis muda yang semasa kehamilan ibunya mendapatkan DES (Tandjung, 1987). Lebih lanjut disebutkan, risiko terdapatnya antibiotika (terutama penicillin dan tetracyclin) yang biasa digunakan sebagai pemicu pertumbuhan dapat juga dialami bila mengkonsumsi bahan makanan hewani. Orang yang terkena risiko antibiotika dari hewan yang dikonsumsinya, akan merasakan tidak lagi dapat menerima antibiotika tersebut secara therapeutik, karena akan terjadi respon-respon allergik yang berat (Rand, 1980 dalam Tandjung, 1987).

Kontaminan bahan tambahan makanan tidak langsung yang berupa molekul elemental (isotop-isotop radiatif) dapat bersumber dari pengujian senjata nuklir atau karena peristiwa perang ataupun sejalan dengan peningkatan pembangunan pusat pembangkit tenaga listrik dengan tenaga nuklir. Sekalipun isotop redioaktif dari pabrik pembangkit listrik tenaga nuklir dapat diatas/dikendalikan, kontaminasi terhadap makanan di masa mendatang tetap akan mengancam kehidupan manusia dan organisme hidup lainnya sebagai akibat dari tidak berfungsinya dengan baik (malfungsi) pabrik-pabrik tersebut (Rand, 1980 dalam Tandjung, 1987).

Jenis kontaminan logam berat (misalnya $\mathrm{Hg}$, merkuri) dapat merusak sistem syaraf pusat (otak). Sumber bahan beracun ini adalah pabrik plastik dengan produk utama berupa vinyl chlorida (Rand, 1980 dalam Tandjung, 1987). Lebih lanjut dilaporkan, bahwa penderita terbesar keracunan merkuri adalah para nelayan yang memakan ikan yang berasal dari perairan yang tercemar dengan merkuri. Tandjung (1987) menyimpulkan, bahwa antara tahun 1953-1960, 53 orang meninggal dunia dan 150 orang menderita kerusakan otak dan syaraf yang berat. Methylmercury $(\mathrm{CH} 3 \mathrm{Hg}+)$ adalah suatu ikatan organik $\mathrm{Hg}$ yang sangat beracun. Seyawa ini disamping merusak sistem syaraf, juga merusak ginjal, hati dan menimbulkan cacat kelahiran yang diduga disebabkan oleh rusaknya kromosoma (Miller, 1975 dalam Tandjung, 1987).

Residu pestisida pada bahan makanan terjadi sebagai akibat aktivitas manusia terutama dalam bidang pertanian. Penanganan yang kurang cermat dapat menyebabkan keracunan akut. Para petani Indonesia umumnya awam atau memiliki pengetahuan yang sangat terbatas tentang penanganan pertanian dengan pestisida. Oleh karena itu, residu bahan pestisida pada produk pertanian Indonesia tergolong tinggi, sehingga sulit diterima sebagai barang impor oleh banyak negara.

Pada era serba teknologi canggih seperti sekarang ini, semua orang berlomba mengejar target, baik sasaran, kepuasan, maupun target produksi yang menjanjikan. Dalam pada itu, sesungguhnya terkandung bahaya tersembunyi yang mengancam kesehatan dan kehidupan yang setiap saat dapat menimpa setiap orang.

3. Pengaruh Bahan Tambahan Berupa Suplemen Hormon dan Antibiotik terhadap Kesehatan Manusia

Kontaminan berbahaya bagi kesehatan dapat tersalurkan kepada konsumen karena mengkonsumsi produk-produk yang terkontaminasi. Kontaminan tersebut dapat berupa logam berat, residu bahan kimia (misalnya pestisida), residu hormon dan antibiotik. Kontaminan logam berat dapat semakin bertambah konsentrasinya karena pabrik, isdustri, pembangkit listrik bertenaga nuklir, perang dan uji coba senjata nuklir. Ada juga jenis tertentu umbi-umbian, daun, buah dan biji, yang kandungan logamnya, terutama seng (Zn) yang tinggi menjadikan dia sangat beracun. 
Kentang dengan zat kandungannya solanin juga bersifat meracuni. Residu pestisida dapat menjadi ancaman serius kesehatan berkaitan dengan rendahnya pengetahuan para petani dalam menangani tanaman pertanian dengan menggunakan pestisida. Demikian juga dengan residu hormonal dan antibiotik pada hewan ternak budidaya. Dengan maksud memicu pertambahan berat badan dan pertumbuhan yang cepat digunakan hormon dan antibiotik, yang pada gilirannya apabila produk daging hewan tersebut dikonsumsi dapat menimbulkan pengaruh negatif terhadap konsumennya.

Kubis dan lobak, dengan zat penghambat penyerapan yodium (zat goitrogen) bisa menyebabkan penyakit gondok. Penyakit kanker (karsinogen), dapat terjadi karena mengkonsumsi makanan yang diberi zat aditif (zat tambahan) seperti: bahan pengawet, pewarna, penyedap rasa, pemanis buatan, dan pengemulsi. Bahan aditif makanan ini juga merupakan zat-zat beracun yang sangat berbahaya bagi tubuh. Penyakit kanker dapat menyerang organ lambung, kolon (usus besar), payu dara dan indung telur. Kanker lambung terjadinya karena zat nitrit dan nitrat dari makanan berubah menjadi nitrosamin yang bersifat karsinogenik. Kanker usus besar, bisa timbul karena bahan makanan yang dikonsumsi mengandung serat rendah dan lemak tinggi. Suatu saat lemak bisa berubah menjadi zat yang bersifat karsinogenik. Kanker payu dara dan indung telur, terjadi karena kadar lemak tinggi.

Kadar lemak tinggi berhubungan dengan pengubahan keseimbangan hormonal (terutama peningkatan hormon estrogen). Senyawa hidrokarbon yang timbul ketika pemrosesan makanan (misalnya dengan pengasapan dan penggorengan dengan suhu tinggi) sangat membahayakan kesehatan. Penyakit kardiovaskuler, merupakan kelanjutan penyakit tekanan darah tinggi, kebiasan merokok, dan kenaikan kolesterol serum. Penyakit ini sangat erat kaitannya dengan jenis makanan yang dikonsumsi (daging, lemak, seafood dan sebagainya) dan kebiasaan negatif lainya (merokok). Lemak hewani dapat menaikan kadar lemak serum, akibabnya kolesterol serum tinggi, pembuluh darah menyempit dan tekanan darah tinggi. Kelompok makanan yang berhubungan dengan penyakit ini adalah: bahan makanan dengan kandungan serat kasar rendah, gula, garam dan protein tinggi, mineral air minum rendah, dan perbandingan antara lemak jenuh dan lemak tak jenuh ganda yang amat tinggi.

Dalam teknologi perternakan, khusus dalam hewan budidaya digunakan zat memicu pertumbuhan berupa hormon dan senyawasenyawa arsenical. Hormon dan senyawa arsenical ini diberikan kepada hewan-hewan ternak beberapa saat maupun selama hidupnya (Tandjung, 1987). Pemberian bahan tambahan makanan pemicu pertambahan berat badan secara cepat (misalnya estrogen sintetik DES), jauh lebih berbahaya dibanding dengan pemberian hormon dan senyawa arsenical yang disebutkan diatas. Mengkunsumsi bahan makanan (daging, telur dan sebagainya) yang mengandung DES (diethylstilbestrol) dapat menyebabkan terjadinya tumor pada saluran kelamin gadis-gadis muda yang semasa kehamilan ibunya mendapatkan DES (Tandjung, 1987). Lebih lanjut disebutkan, risiko terdapatnya antibiotika (terutama penicillin dan tetracyclin) yang biasa digunakan sebagai pemicu pertumbuhan dapat juga dialami bila mengkonsumsi bahan makanan hewani. Orang yang terkena risiko antibiotika dari hewan yang dikonsumsinya, akan merasakan tidak lagi dapat menerima antibiotika tersebut secara therapeutik, karena akan terjadi respon-respon allergik yang berat (Rand, 1980 dalam Tandjung, 1987).

Kontaminan bahan tambahan makanan tidak langsung yang berupa molekul elemental (isotop-isotop radiatif) dapat bersumber dari pengujian senjata nuklir atau karena peristiwa perang ataupun sejalan dengan peningkatan pembangunan pusat pembangkit tenaga listrik dengan tenaga nuklir. Sekalipun isotop redioaktif dari pabrik pembangkit listrik tenaga nuklir dapat diatas/dikendalikan, kontaminasi terhadap makanan di masa mendatang tetap akan mengancam kehidupan manusia dan organisme hidup lainnya sebagai akibat dari tidak berfungsinya dengan baik (malfungsi) pabrik-pabrik tersebut (Rand, 1980 dalam Tandjung, 1987).

Jenis kontaminan logam berat (misalnya $\mathrm{Hg}$, merkuri) dapat merusak sistem syaraf pusat (otak). Sumber bahan beracun ini adalah pabrik plastik dengan produk utama berupa vinyl chlorida (Rand, 1980 dalam Tandjung, 1987). 
Lebih lanjut dilaporkan, bahwa penderita terbesar keracunan merkuri adalah para nelayan yang memakan ikan yang berasal dari perairan yang tercemar dengan merkuri. Tandjung (1987) menyimpulkan, bahwa antara tahun 1953-1960, 53 orang meninggal dunia dan 150 orang menderita kerusakan otak dan syaraf yang berat. Methylmercury $(\mathrm{CH} 3 \mathrm{Hg}+)$ adalah suatu ikatan organik $\mathrm{Hg}$ yang sangat beracun. Seyawa ini disamping merusak sistem syaraf, juga merusak ginjal, hati dan menimbulkan cacat kelahiran yang diduga disebabkan oleh rusaknya kromosoma (Miller, 1975 dalam Tandjung, 1987).

Residu pestisida pada bahan makanan terjadi sebagai akibat aktivitas manusia terutama dalam bidang pertanian. Penanganan yang kurang cermat dapat menyebabkan keracunan akut. Para petani Indonesia umumnya awam atau memiliki pengetahuan yang sangat terbatas tentang penanganan pertanian dengan pestisida. Oleh karena itu, residu bahan pestisida pada produk pertanian Indonesia tergolong tinggi, sehingga sulit diterima sebagai barang impor oleh banyak negara.

Pada era serba teknologi canggih seperti sekarang ini, semua orang berlomba mengejar target, baik sasaran, kepuasan, maupun target produksi yang menjanjikan. Dalam pada itu, sesungguhnya terkandung bahaya tersembunyi yang mengancam kesehatan dan kehidupan yang setiap saat dapat menimpa setiap orang.

4. Pengaruh Bahan Tambahan pada Makanan Berupa bahan Peyedap, Pemanis, Pengawet dan Pewarna terhadap Kesehatan Manusia

Dewasa ini hampir tidak dapat ditemukan bahan makanan yang tidak mengandung bahan tambahan (zat additif), berupa peyedap, pemanis, pengawet dan pewarna. Banyak orang dengan sengaja memberikan bahan tersebut secara berlebihan pada makanannya, tanpa menyadari akibat buruk yang ditimbulkan oleh bahan tersebut bagi kesehatannya. Sangat sedikit orang yang menyadari atau mengetahui dampak buruk zat aditif pada makanan terhadap kesehatan. Misalnya bahan makanan kemas, hampir seluruhnya menggunakan bahan pengawet makanan dan pewarna (zat aditif). Berbagai jenis bahan pengawet dan pewarna yang digunakan manusia pada makanan ternyata mempunyai efek yang sangat merugikan kesehatan manusia baik dalam waktu jangka panjang maupun jangka pendek berupa meningkatnya resiko: metaboliseme abnormal, kelahiran abnormal dan derajat kematian abnormal.

Tulisan ini menyajikan pengaruh bahan tambahan (zat additif) khususnya berupa bahan penyedap, pemanis dan pengewet pada makanan. Diantara jenis bahan tambahn (zat additif) yang paling banyak digunakan orang adalah bahan penyedap berupa Monosodium Glutamat (MSG) atau lebih populer dikenal dengan istilah Vetsin. Bahan tambahan ini (MSG) dapat menimbulkan berbagai jenis gangguan pada kesehatan manusia seperti rasa mual yang disertai rasa pusing yang cukup berat, debaran jantung yang lebih kuat, dan kesemutan. Salah satu sifat toksik (racun) yang disebabkan oleh bahan penyedap (vetsin) adalah sifatnya sebagai racun syaraf. Budiarso dkk. (1977) menemukan efek pendarahan pada beberapa bagian tubuh hewan percobaan dan efek endema dalam jaringan pengikat di bawah kulit. Olney (1969) dan Nikolesseas (1977) menemukan kelainan pertumbuhan tulang pada hewan percobaan, Tangendjaja (1981) menemukan gejala menggigil yang tidak bisa sembuh pada bayi yang diberi MSG dan kelainan otak pada anak berusia 10 tahun yang diberikan MSG.

Sifat neurotoksik MSG tersebut di atas, mendorng komisi bersama FAO dan WHO untuk mengumkan ADI (Acceptable Daily Intake) untuk MSG bagi manusia adalah sebesar $120 \mathrm{mg} / \mathrm{kg}$ berat badan. Hasil simposium oleh perhimpunan Hotel Indonesia menyimpulkan bahwa MSG tidak lagi tepat disebut sebagai "Bumbu" mengingat efeknya yang sangat beracun, namun masih cukup banyak masayarakat konsumen yang tidak dapat lepas dari ketergantungannya akan bahan penyedap ini.

Bahan permanis yang paling terkenal adalah Cyclamat dan saccharin yang digunakan sebagai pengganti gula tebu. Cyclamat memiliki rasa manis sekitar 30 kali gula tebu, dan saccharin memiliki rasa manis sekitar 300 kali manis gula tebu.

Hasil penelitian menunjukan bahwa pemberian Cyclamat pada bahan makanan menyebabkan kanker pada kandung kencing 
(Turner, 1970, Kiatanto, 1979). Pemakaian cyclamat yang direkomendasikan oleh The National Academy of Sciences, 1968 adalah 70 $\mathrm{mg} / \mathrm{kg}$ berat badan per hari. Menurut Peraturan Menteri kesehatan RI No 100179/A/SK/74, tanggal 8 Nopember 1974 mengenai zat pemanis buatan yang diijinkan pada makanan dan minuman untuk cyclamat dan saccharin disajikan pada Tabel 1.

Tabel 1. Jenis Makanan dan Kadar Maksimum

\begin{tabular}{|l|l|l|}
\hline Makanan & $\begin{array}{l}\text { Zat Pemanis } \\
\text { buatan }\end{array}$ & $\begin{array}{l}\text { Kadar } \\
\text { maksimum } \\
(\mathrm{ppm})\end{array}$ \\
\hline $\begin{array}{l}\text { Berkalori } \\
\text { rendah }\end{array}$ & $\begin{array}{l}\text { Sakarin } \\
\text { Cyclamat }\end{array}$ & 0,15 \\
2,00 \\
\hline $\begin{array}{l}\text { Untuk } \\
\text { penderita } \\
\text { diabetes }\end{array}$ & Sakarin & 0,15 \\
\hline Minuman & Cyclamat & 2,00 \\
\hline & Sakarin & 0,005 \\
Cyclamat & 0,06 \\
\hline
\end{tabular}

Bahan pemanis tersebut di atas, selain menimbulkan kanker pada kandung kencing, menyebabkan berbagai penyakit seperti: tumor pada paru-paru, indung telur, ginjal, kulit dan uterus, menganggu proses penggumpalan darah, kematian sel, kerusakan kromosom, penyakit jantung, dan diabetes (Rand, 1980). Para ahli farmasi dan teknologi pangan sangat menganjurkan agar kita jeli terhadap makanan kemas, dan mengutamakan bahan makanan segar. Penggunaan bahan makanan kemas berkembang bersama dengan perkembangan urbanisasi, yang menuntut pengawetan makanan agar dapat bertahan selama berhari-hari, berminggu-mingu, bahkan bertahuntahun. Selain itu (pengawetan), berkermbang pula keinginan untuk memperindah kemasan dengan warna agar lebih manarik. Bahaya terbesar yang sering dihadapi manusia dalam sektor idustri makanan adalah keracunan akibat bahan pengawet dan pewarna (zat aditif) yang digunakan pada makanan kemas. Penggunaan bahan makanan kemas berkembang bersama dengan perkembangan urbanisasi, yang menuntut pengawetan makanan agar dapat bertahan selama berhari-hari, berminggu-mingu, bahkan bertahun-tahun. Sejalan dengan perkembangan usaha pengawetan bahan makanan ini berkembang pula perlambatan daur biogeokimia yang mencegah pemecahan alami oleh populasi mikroba terhadap bahan makanan tersebut. Berbagai jenis bahan pengawet yang digunakan manusia ternyata mempunyai efek jangka panjang maupun jangka pendek berupa meningkatnya resiko: a) metaboliseme abnormal, misalnya mengganggu cirkulasi darah melalui berbagai mekanismenya. Misal menghambat penyerapan vitamin $\mathrm{K}$ yang akan berpengaruh dalam proses pembekuan darah, menutup permukaan mitokondria sehingga menghambat respirasi dan bahkan menghentikan aktivitas (mematikan sel, jaringan, sistem jaringan, organ) sehingga mengakibatkan kelumpuhan atau bahkan kematian; b) kelahiran abnormal, hasil penelitian pada beberapa ternak menunjukan adanya pertumbuhan abnormal pada beberapa organ tubuh hewan percobaan sebagai pengaruh pemberian zat pengawet dan pewarna; c) derajat kematian abnormal.

Dengan adanya resiko seperti tersebut di atas, Pemerintah melaui Keputusan Menteri Kesehatan RI Nomor 1/1332/A/SK/73, tanggal 22 Oktober 1973 telah menetapkan Daftar Zat Warna bagi makanan dan minuman yang diizinkan bagi manusia; dan Kepmen Kesehatan RI No. 10177/ASK/74, tanggal 28 Nopember 1974 telah menetapkan jenis-jenis bahan pengawet dan menentukan kadar maksimum yang diijinkan pada setiap produk bahan makanan.

Dari uraian di atas dapat dismpulakn bahwa: 1) pemberian bahan pengawet dan pewarna pada makanan berakibat kurang baik dan bahkan sangat buruk bagi kesehatan manusia; 2) penggunaan bahan penyedap (MSG/ Vetsin) dan pemanis (cyclamat dan saccharin) pada bahan makanan menimbulkan berbagai gangguan kesehatan seperti rasa mual yang disertai rasa pusing yang cukup berat, debaran jantung yang lebih kuat, dan kesemutan; 3) bahan tambahan yang berupa pemanis (cyclamat dan saccharin) menimbulkan berbagai penyakit seperti tumor paruparu, indung telur, ginjal, kulit dan uterus, mengganggu proses penggumpalan darah, kematian sel, kerusakan kromosom, penyakit jantung, dan diabetes (Rand, 1980).

\section{Kesimpulan}

Dari uraian dan pembahsan mengenai dampak negatif zat aditif pada makanan terhadap kesehatan manusia di atas, dapat disimpulkan bahwa pemberian bahan pengawet, pemanis dan pewarna (zataditif) pada makanan berakibat kurang 
baik dan bahkan sangat buruk bagi kesehatan manusia. Gangguan kesehatan dapat berupa gangguan pertumbuhan dan perkembangan tubuh, rasa mual yang disertai rasa pusing yang cukup berat, debaran jantung yang lebih kuat, dan kesemutan, tumor pada paru-paru, indung telur, ginjal, kulit dan uterus, proses penggumpalan darah, diabetes melitus, kematian sel, kerusakan kromosom, penyakit jantung dan kematian. Oleh karena itu, maka upaya penyadaran masyarakat mengenai dampak mengkonsumsi makanan yang mengandung zat aditif terhadap kesehatan perlu mendapat perhatian semua pihak agar masyaraakat terutama generasi muda sadar dan waspada dalammenyeleksidan memilih makanan yang hendak dikonsumsinya.

\section{Daftar Pustaka}

Holdgate, M.W., 1980, A Prospective of Environmental Pollution, Cambridge University Press, Cambridge.

https://halosehat.com/farmasi/aditif/zat-aditifpada-makanan-contoh-bahayanya.

Saturday 03rd, February 2018

http://sinma68.blogspot.co.id/2010/12/zataditif-pada-makanan-dan-

bahayanya.html. Saturday 03rd, February 2018

https://www.academia.edu/4394523/Dampak Negatif_Penggunaan_Zat_Aditif_pada Makanan. Saturday 03rd, February 2018

Kusnadi, K.A., 1993, Dasar-Dasar Anatomi dan Fisiologi Tubuh Manusia, Jurusan Pendidikan Biologi FPMIPA, IKIP Bandung, Bandung.

Tandjung, H.S.J., 1987, Ancaman Keracunan oleh Adanya Bahan-Bahan Tambahan di dalam Makanan, Makalah, Universitas Gadjah Mada, Yogyakarta. 